Pakistan Journal of Humanities and Social Sciences

October - December 2018, Volume 6, No. 4, Pages 582 - 599

\title{
A Review of Foreign Direct Investment and Manufacturing Sector of Pakistan
}

Saif ur Rahman ${ }^{1}$ and Nor'Aznin Abu Bakar ${ }^{2}$

${ }^{1} \mathrm{PhD}$ Scholar, School of Economics, Finance and Banking (SEFB), College of Business (COB), Universiti Utara Malaysia.

${ }^{2}$ Associate Professor, School of Economics, Finance and Banking (SEFB), College of Business (COB), Universiti Utara Malaysia.

Email: saifrao12@gmail.com

\begin{abstract}
The objective of this study is to explore the insights of the literature on foreign direct investment (FDI) toward manufacturing industry in the context of developing economies. This paper examines and synthesizes existing theoretical and empirical literature on said issue. It first draws the overview of the FDI and manufacturing sector in Pakistan. Second, it identifies the literature based on the theoretical and empirical insights from the published literature. In addition, this article put light on theoretical methods that describes how/ why these methods work. Third, this article proposes three fruitful dimensions for further research. This paper contributes to the area of FDI and manufacturing sector growth by critically analyzing and synthesizing existing theory and research on FDI and growth of manufacturing sector.
\end{abstract}

Keywords: Foreign Direct Investment, Manufacturing Sector

\section{Introduction}

In the last few decades, trade barriers are minimized due to the progressive liberalized economic policies that have been promoted globalization (Dar, Bhatti, \& Muhammad, 2017). Due to this liberalized concept contemporary economic setup was complemented by in liberalized economies (Fauzel, Seetanah, \& Sannasee, 2015). Due to the free trade by the economic policies, have been achieved massive growth in terms of massive human and physical capital. The FDI inflows in developing world has also a source to promote economic growth. FDI refers to the cross-border investments by an enterprise with the purpose of obtaining long-term benefits in other countries(Wang, Hong, Kafouros, \& Wright, 2018). The long-term benefits represent the influence of direct investors towards the enterprise management through the possession of a minimum 10 percent of voting power (OECD, 
2013). Generally, it involves participating in joint-ventures, management, expertise and technology transfer. Besides that, FDI is also known as the growth enhancing factor in developing countries as it has the potential to create employment, enhance skills and transfers technology, productivity and improve long term socio-economic development (Eichengreen $\&$ Tong, 2007). Thus, the most developed and least developed countries are equally involved in the FDI activities to accelerate economic growth in their respective countries. In developing countries, FDI has been considered as potential source of development for the novel and small domestic firms (Wang et al., 2018).

On the ground of economic growth of every country, FDI have considerable important determinant of economic growth. whereas, manufacturing FDI contributes to host country economic growth only when it has enough absorptive capacity to adopt the advanced technologies (Borensztein, De Gregorio, \& Lee, 1998; Fauzel et al., 2015) But FDI is a remarkably important variable for growth in transition economies, as its effect on economic growth is positive and statistically significant in transition economies (Campos \& Kinoshita, 2002). In the same way, manufacturing FDI is positively correlated with economic growth and accelerate country's growth with the condition of adequate human capital, trade liberalization and economic stability (Bengoa \& Sanchez-Robles, 2003; Wang, 2009). Furthermore, the relationship between growth of manufacturing and Foreign Direct Investment (FDI) has extensive importance in the economic history. There are strong conceptual evidences available to prove that FDI can improve economic growth and performance of manufacturing, while the empirical evidence is divided, most of the studies shows a strong relationship among economic growth and manufacturing FDI in the context of developing and developed countries as well (Borensztein et al., 1998; Hussain, 2017).

Correspondingly, In the context of Pakistan manufacturing sector is an important determinant of Pakistan economic growth. It is the key contributor for production, employment, exports \& investments. FDI, through its participation in the manufacturing sector investments, is contributor for further enhancement of growth process of the economy (Hussain, 2017). Among several other factors, it is the state of art technology, which enhances the growth of output in the manufacturing sector, can raise the productivity and growth of output of the FDI firms (foreign firms) in the manufacturing sector. FDI is considered as source to expand small and unexperienced local firms in the developing economies (Blomström, Kokko, \& Mucchielli, 2003; Dar et al., 2017). By the following such policies, developing countries such as Pakistan, can boost foreign trade up and also act as investors in 
the host country and on the other hand act as producers and consumers across borders (Eichengreen \& Tong, 2007).

\section{A. Overview of FDI and Manufacturing Sector of Pakistan}

From the last decade, number of countries in the world particularity the developing economies want to get the attention of foreign investors to invest in their domestic firm particularly in the form of FDI. The increasing trend of foreign investment in an economy provides many benefits including capital inflow, increase employment opportunities, enhance employees 'wages, technological development and spillover which increase the productivity of domestic firm finally enhances economic growth (Cipollina, Giovannetti, Pietrovito, \& Pozzolo, 2012). Figure 1.4 depicts the FDI net inflows measured in millions of dollars in Pakistan. It can be observed from the figure that FDI in Pakistan has been decreasing since 2007. The decreasing trend continues until 2012, when it gets little increasing trend and reaches to US\$1000 million in 2016.

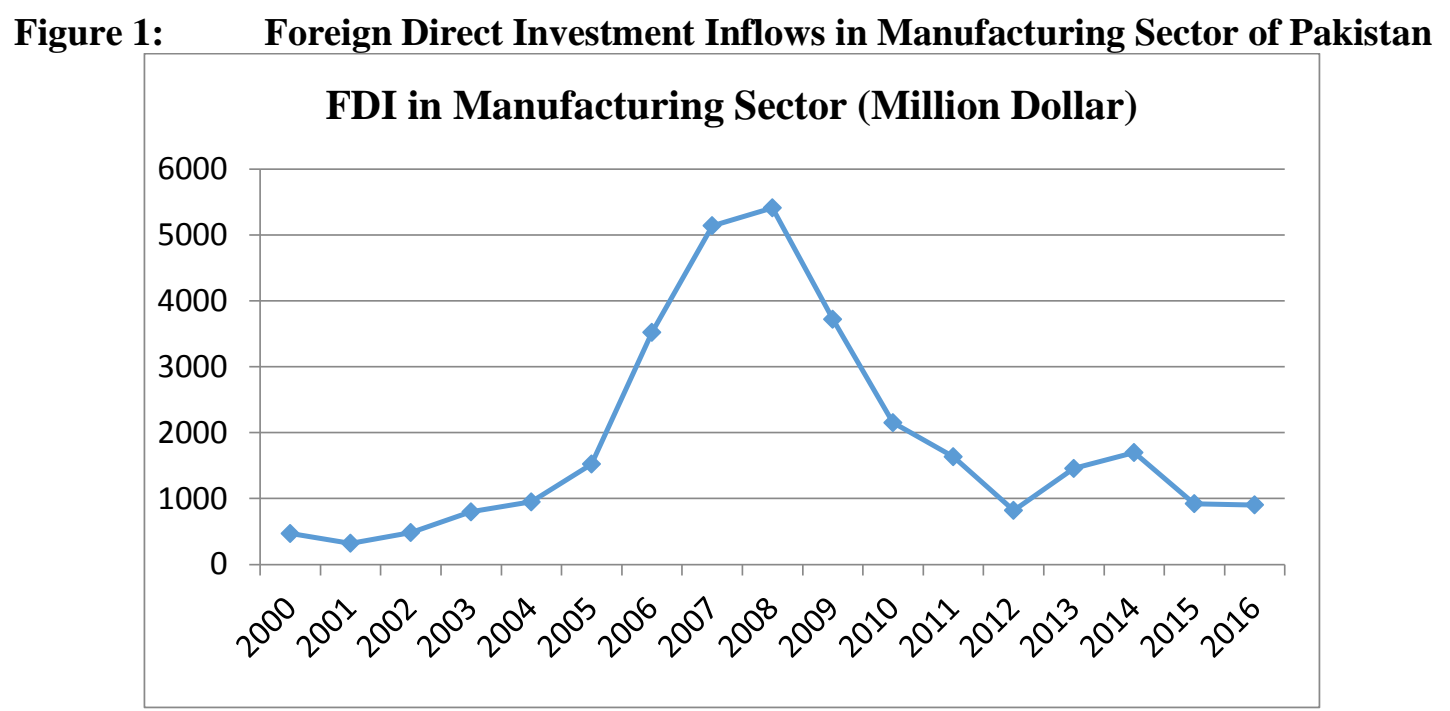

Source: State Bank Pakistan, Annual Report 2016-2017

The importance of manufacturing sector cannot be neglected due to its significant share in Pakistan's exports and employment generation. FDI is significantly contributing to the growth of manufacturing sector. Among several other factors, it is the state of art technology, which enhances the growth of output in the manufacturing sector. FDI, through transfer of the state of art technology, can raise the productivity and growth of output of the FDI firms (foreign firms) in the manufacturing sector. According to the past research, there are many factors affecting FDI and each different country has their own major determinants of FDI depending on their level of income. As stated by Yasmin, Hussain, and Chaudhary 
Pakistan Journal of Humanities and Social Sciences, 6(4), 2018

(2003) FDI for upper and lower middle-income countries and trade openness, external debt, labor force and domestic investment, whereas urbanization, market size, wages, current account and inflation are the determinants for lower income countries.

Interactions between FDI and human capital strive influence to attain economic growth (Balasubramanyam, Salisu, \& Sapsford, 1999). Furthermore, FDI and trade are considered as catalysts for achieving desired rates of growth in developing economies. While the effect of total FDI on growth is ambiguous, and as a negative effect of investments is evidenced in case of primary economic sectors, however, a positive FDI effect is found in case of manufacturing sector(Alfaro, Chanda, Kalemli-Ozcan, \& Sayek, 2004). The study of Akinlo (2004) on FDI postulated that it economic growth is not always the outcome of FDI.

The economy of Pakistan heavily rely on foreign finance and technology since it is a capital-scarce country (Rehman, 2016). Many factors are responsible for this poor performance. Unfortunately, the economy of Pakistan has been suffering from higher inflation rates, increased population growth, political disruptions, internal and external disputes on the borders since last two decades. Inadequate levels of investments caused by poor savings give birth to poor socio-economic infrastructure which cause lower growth rates in most of macroeconomic indicators (Zaman, Shah, Mushtaq Khan, \& Ahmad, 2012). The critical role of FDI in the growth phenomenon cannot be neglected. As argued by Trevino, Thomas, and Cullen (2008)that the development rate of novel technologies and products is higher in case of transnational corporation (TNCs) as compared to domestic corporations, which in turn exert a competition pressure thereby enhancing the intimation and innovation process among domestic firms.

The doors of Pakistan are open to FDI like other developing economies in anticipation of inward economic benefits, though it has not been as successful as India and China, the neighboring countries, in attracting consistent and significant inflows of FDI. Also, the underutilization of inward FDI to enhance economic activities is another point to ponder in developing economies(Ataullah \& Le, 2006). This might be due to inappropriate economic reforms that failed to attract sufficient amount and kinds of FDI in these countries because the structural composition and kind of FDI matters for desired economic outcomes (Chakraborty \& Nunnenkamp, 2008).

\section{Manufacturing Sector Performance and growth}

In the last five years, according to the sectorial growth, it has been observed that the tertiary sector is a significant economic driver in Pakistan. Table 1 shows that growth of 
services attributed to the booming level. On the other hand, industrial (manufacturing) sector share followed a declining trend and this sector is considered as the primary sector after the agriculture sector. Moreover, it has also been revealed from the sectorial analysis that the manufacturing (industrial) sector is among the major contributors of Pakistan's economy with $20.8 \%$ share in country's GDP.

Table 1: Sectoral contribution in GDP in Pakistan

\begin{tabular}{|llrrrrrc|}
\hline No & Sector & $\mathbf{2 0 1 1 - 1 2}$ & $\mathbf{2 0 1 2 - 1 3}$ & $\mathbf{2 0 1 3 - 1 4}$ & $\mathbf{2 0 1 4 - 1 5}$ & $\mathbf{2 0 1 5 - 1 6}$ & $\mathbf{2 0 1 6 - 1 7}$ \\
\hline 1 & Agriculture & $21.00 \%$ & $21.40 \%$ & $21.00 \%$ & $20.90 \%$ & $19.82 \%$ & $19.53 \%$ \\
2 & Industrial & $21.00 \%$ & $20.40 \%$ & $20.45 \%$ & $20.67 \%$ & $21.93 \%$ & $20.88 \%$ \\
3 & Services & $53.50 \%$ & $57.70 \%$ & $58.10 \%$ & $58.80 \%$ & $59.16 \%$ & $59.59 \%$ \\
\hline
\end{tabular}

Source: Pakistan economic survey (2016-17)

For the overall economy, manufacturing sector plays a significant role specifically in the developing countries. With the increase in the investment from the investors, manufacturing products increase as well, and such investments lead boost growth of the economy (Schauer et al., 2017). As per the findings of manufacturing sector research, this sector works as an engine in the growth of developing economies with the two major reasons. The first is that scope of learning and productivity will be larger and rate of productivity and growth for the manufacturing will positive dependency on the output growth rate in manufacturing as well. At second, manufacturing sector of the economy can increase the growth productivity due to its link with the other non-manufacturing sector. It also focuses on the human capital which at the end discretionary expenditure in the overall economy and provide benefit to other sectors as well.

\section{Literature Review}

This section provides literature on the effect of FDI on economic growth in general and manufacturing sector growth. Additionally, the studies that included domestic investment as independent variable has also been reviewed in this section. There is an empirical and theoretical level of association between the industrialization and per capita income levels in the context of developing economies. This is due to the reason that such actor leads to the huge injection of capital in the economy and have multiple effect on the economy. With such significant effect, people have the job opportunity in the economy which also increase the per capita income and its growth (Kaldor, 1966; Rodrik \& Subramanian, 2009). Besides, it is also examined that the link and spillover effect between all these factors are under observation from the context of manufacturing and other sectors in the economy (Szirmai \& Verspagen, 2015). Like other sectors in the economy, the role of manufacturing is very much 
significant and over quarter to quarter its role is very much important to consider studying the overall economy.

In various studies, FDI and relevant findings have been presented both from empirical and theoretical perspective. For instance, have considered the vital impact of FDI for the other selected indicators. Researchers has found that FDI is very much significant in the amplification of economic growth, for the employment creation, increasing level of productivity and causing a spillover effect for the technological development (Fauzel et al., 2015). Besides, FDI has positive and consecutive effect of technological advancement with the economic growth. however, the impact of FDI on economic growth regarding sectorial growth is very much important to address and discuss.

\section{A. Theoretical Review}

In the economic literature, findings of the study have explained the fact that various economies become rick and middle-income status, with the key contribution of manufacturing sector in GDP; about 20 to 35\%. Besides, level of consumptions shifts towards the service, with the hiring of services in the job output and sharing of manufacturing in GDP. The level of industrialization requires significant amount of money but among the key issues for the developing and poor economies is that they don't have enough amount of saving in their budgetary level to support their investment (Cipollina et al., 2012).

Libanio and Moro (2006) have examined the relationship between industrial growth and level of GDP with the effect of manufacturing sector on productivity level for the overall economy. The findings of the study have confirmed the idea that manufacturing sector is known as the engine for the economy. An and Jeon (2006) further have investigated the hypothesis for the manufacturing sector as an engine of economic growth; Kaldorian approach for the growth in the Chinese economy over the time duration of 1979 to 2004 with the usage of both time series and panel regression model. he has found that all the empirical findings are in support for the stated hypothesis which plays a good role in overall GDP of Chinese economy. Similarly, Singh (2017) have investigated the manufacturing sector as the most significant engine for the growth and development, in the developing countries, findings of this reveals that there exists a positive association between the degree of industrialization and per capita income in the developing states. Meanwhile, manufacturing sector in the developing sector is considered as the biggest absorber for the labor force with the major contribution in the overall GDP for the Asian economy. Besides, manufacturing is normally regarded as the synonym for the industrialization which is driven the by the capital and 
similar requirement, with the absence of national saving, developing economies are under some crisis to finance their investment.

Furthermore, Chen, Geiger, and Fu (2015) have examined the industrial development and its effect on the Nigerian economy and its growth over 1973 to 2013 with the OLS regression estimation. They have found that industrial influence has a significant influence on economic growth. In another study, (Chandran, 2009) investigated both short as well as longterm effect of FDI, and he has considered the manufacturing growth for the Malaysian economy over 1970 to 2003 by implementing a latest co-integration approach, using ARDL model. they have found that FDI in both long and short run has significant influence with $1 \%$ increase, causing a positive change of $11.5 \%$ in the value addition growth of manufacturing sector. The empirical findings explain that FDI has a major role to play for the stimulation of growth in the economy in the context of Malaysia. Besides the significance of FDI, they have suggested that focus is also needed for the human capital from the context of Malaysia.

Moreover, Research work of Wong, Loh, Lim, Lam, and Lim (2015), have examined association for the FDI and manufacturing growth in the context of Nigeria by using the OLS regression. A significant positive association has been found between aforementioned variables in Nigeria. For the growth effect of FDI and investment in the form of portfolio, have considered 126 countries from 1985 to 2002 while using the dynamic panel regression models. GMM approach explains the idea that although FDI has a positive and significant influence on growth in the context of developing economies with the lower and middleincome states. While applying the system GMM approach, it is found that in developing economies, economic development and absorptive capacity has a growth enhancing effect for the investment inflows. Ahmed (2012) further found the effect of FDI on the labor force, human capital and level of absorptive capacity with the physical capital. He investigated the effect of FDI on all these economic factors while taking the physical capital as control indicator of the model from the context of Malaysia. Findings of the study, by using the OLS explains that FDI inflow has negative contribution towards the total factor productivity (TFP). The effect of FDI on economic growth is found to be significant.

While, Mahmood and Siddiqui (2000) have measured the TFP for manufacturing (industrial) sector of Pakistan from 1972 to 1997. They also have found that with the increase in $\mathrm{R} \& \mathrm{D}$ expenditure, technical and manpower with the growth of knowledge in human capital has a significant influence on the value of TFP in manufacturing. Besides, in the study of it is empirically investigated the validity of Kaldorian approach to growth and development in the 
Pakistan Journal of Humanities and Social Sciences, 6(4), 2018

region of Pakistan using annual data between 1964 and 2008. By using the OLS regression estimation, it is found that growth of GDP is much associated with manufacturing growth as compare to other sector like agriculture or service. Therefore, Manufacturing sector has presented a forward and backward link to service and agriculture sector. Both have ultimate positive influence on the economic development of Pakistan as they are attributed to the GDP in Pakistan.

\section{B. Empirical Review}

As the past empirical investigations have suggested that FDI capital inflows are not as much unstable as other types of capital inflows (World Economic Outlook, 2007). Whereas, it involves a long term duration of commitment (Barrell \& Holland, 2000; Blomström et al., 2003). Therefore, FDI not only consist on the financial capital that is a technological capital, intellectual capital (managerial skills), entrepreneurship and market access (Dunning, 1993; Dunning, 1998). FDI derived through the several benefits that have developed the interest among policymakers in terms of the FDI's potential impact and the policies that might affect FDI inflows. Additionally, evidence shows that, FDI undeniably act in better growth outcomes (Borensztein et al., 1998; Dunning, 1998).

By analyzing the literature author found number of studies, for instance, Xu (2000) has considered the investment of US for 40 countries over 1966 to 1994 and found that transfer of technology from US increase the productivity and growth in various regions. But this growth is subject to the developed economies with the advancement of technology and not the same for the emerging economies. Researchers like Agosin and Mayer (2000) have considered the influence of lagged value of FDI on the investment rate in the host states to investigate the statement that whether the impact of FDI is crowd-in or crowd-out for the domestic investment during 1970 to 1995. Conclusively, it is found that that FDI crowded in the domestic investment in the region of Asia and Latin America.

Chuang (2007) have scrutinized the impact of FDI and relevant decision on the level of investment at domestic glance. They have considered the manufacturing firms of Taiwan, while data is collected from Industrial Development Bureau from 1993 to 1999. They have also considered the deferral effect for the FDI on the size of the firm and endogenous switching model for the correct estimation. Their empirical findings explain that FDI significantly influence the value of manufacturing firms and their decision making. In addition, when the business firms are engaged in defensive FDI, a crowding out effect is found. At the end, a positive effect of FDI has been found on the larger firms while for the 
smaller firms, this effect is positive as well. In addition, De Gregorio (1992) have examined the panel of 12 states from Latin America and found that there exists a significant positive relationship with the FDI and economic growth. additionally, the study has provided the idea that FDI allow the developing states to make exchanges with other countries with the overall positive influence on economic growth.

Furthermore, Castejon and Woerz (2006)has explored the impact of FDI on the productivity and its growth rate by using the panel data. Empirical analysis of the study explains that impact of foreign investment on the growth of the country. They have indicated that FDI has a significant and positive impact for the developing economies as compare to under developed states. Nadiri (1993) further examined the association of FDI and economic growth in the US economy with the capital and growth in manufacturing sector in Japan, France, Germany and UK as well. Borensztein et al. (1998) have examined a positive influence of FDI on the developing economies. but it is also reported that minimum threshold level of technology is also found.

While, in the context of Pakistan, Sharafat, Rashid, and Khan (2014) found that FDI, with the value of service debt and inflation has significant influence on the economic growth. the method of analysis was cointegration and granger causality approaches. In addition, it is found that FDI and MNCs are not able to increase the level of total factor productivity TFP in the selected region. But the output for the developed nation is opposite and these factors have significant positive influence (Ashraf, Herzer, \& Nunnenkamp, 2016). In addition, some of the studies conducted in past revealed that FDI also has negative and significant impact for the growth due to the reason that local business firms have a significant grip and growth in the market with labor force and create challenges for the MNCs to hire some labor for their business (Liu \& Zou, 2008). Correspondingly, Falki (2009) further analyzed the impact of FDI on the growth of Pakistan for the time duration of 1980-2006. The point of focus is based on the endogenous growth theory while taking both FDI and growth into final consideration with the factor of production. Other economic indicators like domestic investment, trade, labor force is also used in the analysis. Findings of the study have explained a significant and negative relationship among FDI and GDP in the context of Pakistan.

\section{Positive impact of FDI on Manufacturing Sector Growth}

It is evident that by the support of previous literature, FDI is the key source to increases growth of the local firms by gaining the efficiency and through the productivity. Whereas, the empirical evidences are not common. The evidence that are available for 
developed countries more likely to return the concept that the output of local firms, are positively corelated to foreign firms presence in the host country (Fauzel et al., 2015). Under the title of FDI various factors like knowledge, capital stock and level of technology with the management practice are captured. In addition, skill and competencies, level of training and organizational development. besides, in the developing countries, level of FDI has significant and impact on the economic growth ((De Mello, 1999; Nambiar \& Balasubramaniam, 2016). They have postulated that level of FDI in the host region significantly depend on human capital and other factors. it is also found that FDI has brought an advance level of technology to the host country which will return increase the level of productivity and finally the growth in the economy and also stimulates the level of fixed assets and investment with the reasonable level. For the export-oriented strategy, the effect of FDI for 46 countries over the time of 1970 to 1985 have been found to be significant and positive in the study of Balasubramanyam, Salisu, and Sapsford (1996).

By using the data in the form of time series to examine the association between FDI and other determinants for the growth of Malaysian firms, Chang and Wong (2005) has selected the time of 1980 to 2002. He has found that with the good and significant rate, manufacturing sector has significantly attracted the FDI in Malaysia. Another study of Chang and Wong (2005) have explained that FDI has significant impact on the value of growth rate. Their study has used the time series data to examine the relationship between local investment and their impact on the long run growth along FDI. Conclusion of the study indicates that all investment types have significant and positive impact on Malaysian economy. Another study found that the flow of FDI has a significant and positive impact on the growth for the sample of 23 developed economies and 73 developing states. After the consideration of combine sample, the sample of 73 countries of developing economies are divided into two major groups based on the per capita income, that found that effect of FDI on the growth of the economy is positive but not significant. It is also explained that less developed states are very slow in learning from the MNCs due to the reason that domestic firms are far behind in their technological advancement.

Furthermore, Borensztein et al. (1998). Conducted a study by focusing on 69 developing regions with the focus on human capital for the absorbing capacity of foreign level of technology. With the higher HC, the level of FDI inflow is very much significant, they have concluded that impact of FDI differs from state to state with the human capital. Higher level of human capital will encourage the level of FDI in the state (Borensztein et al., 
1998). Likewise, Wang (2009) have argued that diversified findings in the relationship between FDI and growth of the economy is because of taking FDI in aggregate format. For this purpose, he has taken the sector wise data for the FDI inflow in the economy for 12 Asian states. Time duration of the study was 1987 to 1997 and it is found that in manufacturing sector performance of FDI is very much significant and positive but not the same for the nonmanufacturing firms. Similarly, By applying the panel data for 90 countries Johnson (2006) further examined that level of FDI has a significant impact with the spillover effect of technology and inflow of physical capital. He further found that FDI inflow can increase the growth of the economy in the developing states. Additionally, he provided a good review for the empirical literature based on the economic growth and FDI.

In addition, number of researchers investigated the FDI effect in the different economies on the manufacturing and economic growth for instance, Pradhan and Singh (2008) investigated the FDI on the growth of the Latin American states, Almfraji and Almsafir (2014) have examined the effect of FDI for the economic growth both in direct and indirect way. It is found that over the time of 1994 to 2012, the effect of FDI on the economic growth is significant and positive. For this association, various indicators like human capital, improved financial market plays their significant role as well. Similarly in the Pakistan, Ghazali (2010) have investigated the relationship between FDI, level of domestic investment and GDP growth for the Pakistan over 1981 to 2008. Findings of the study indicate that for the FDI ad domestic investment, there exists a bidirectional association and causality, positive correlation with FDI, domestic investment and growth, positive association under cointegration method in FDI, domestic investment and growth. all these findings have stated the fact that in Pakistan FDI has a significant positive influence over the value of GDP growth. Such relationship not only influence the foreign investors but also promote the level of domestic investment in the country. To conclude that the past literature reveals that there is a long-term relation among FDI flows and the growth of Pakistan economy, (Riahi-Belkaoui, 2003; Younus, Sohail, \& Azeem, 2014; Zeb, Qiang, \& Rauf, 2013) and promote domestic investment and exports, (Ghazali, 2010; Zaman et al., 2012).

\section{Negative Effect of Foreign Direct Investment on Growth of Manufacturing Sector}

Various earlier studies have found insignificant impact of FDI on the economic growth in the developing and host countries. FDI negatively affect the growth of the economy, if foreign investors and their business firms will remittance huge amount of profit to their home country. For instance, in the study of it is found that FDI has very little or no 
significant influence on the value of economic growth for the sample of 73 developing economies. In another study, has found an insignificant effect of FDI inflow on medium and long-term economic growth per capita income for the sample of 41 developing economies. In the study of it is explained that FDI has negative influence over the value of skill-upgrading (Blonigen \& Slaughter, 2001). Edison, Levine, Ricci, and Sløk (2002) have confirmed his findings in a sense that FDI has a negative impact on the growth of various states with the using of cross country analysis over 1960 to 1995 . Meanwhile, FDI inflows does not have any effect on the growth of the economy (Carkovic \& Levine, 2005).

Similarly, the impact of FDI on the growth of manufacturing sector is experienced with the negative impact both in the title of panel and time series econometric modelling as explained by (Mencinger, 2003). However, the flow of FDI is greatly depends on the absorption capacity of the technology. In the study of Durham (2004) it is found that FDI has a negative but insignificant impact on the growth of the economy. In another study of (Khan, 2007) it is observed that FDI and role of domestic growth of financial sector was expected to improve with the reinforcement of the link between the both. The time duration of the study was 1972 to 2005 which has considered the growth rate of GDP, ratio of FDI to real value of GDP, development of financial sector, physical capital, labour. By testing the approach of bound methodology with the cointegration and ARDL, results of the study have provided some significant facts.

On the other hand, Liu, Daly, and Varua (2012) explored the existence of a negative association between FDI and growth for the manufacturing sector. They have shown that with the expansion of manufacturing sector, the skill and abilities of labor force are very much significant. But at the same time, it is found that higher value of labor force causes higher cost of production when can negatively affect the value of FDI in the domestic market for the host countries. similarly, in terms of economic growth, Mazenda (2014) examined the FDI among other indicators like flow of capital and growth in the economy. It is found that FDI can also lead to the employment, technological advancement, managerial skill and other benefit to the economy. The time duration is from 1980 to 2010 with the Johansen co-integration method and Vector error correction approach to examine the effect of key indicators on the south Asian economies. Findings of the study explain that FDI, real exchange rate and debt factors have negative impact on the growth of the economies. Correspondingly, in the middle east, the study of (Frankel, 2012; Frankel, Parsley, \& Wei, 2012; Nabli \& Arezki, 2012) has been conducted to check the performance of macroeconomic factors with the slow level of growth 
rate. The level of foreign investment brings a significant change in the value of natural resources and exchange rate stability which finally reduce the financial uncertainty in the selected economies.

\section{Methodology}

In this study author following the literature review procedure under the principles of systematic literature review (Jesson, Matheson, \& Lacey, 2011) to collect and critically analyze the relevant literature. For the comprehensive and critical analysis, author develop a critical review form to analyze several key points of the previous studies namely focus of the paper, bibliographic details, theory used (where relevant), research philosophy (Zikmund, Babin, Carr, \& Griffin, 2013), key findings, methodology, definition of FDI, FDI domain, research context, geographical location of the study, theoretical and practical review, and further conclusion and reported limitations.

For the critical review of this study, author searched literature since November 2017 to April 2018. To identify utmost relevant FDI papers as possible, after identification of the papers researcher conducted a comprehensive search by evaluating in the relevant papers downloaded from (1) Economics journals listed in the clarivate analytics (The Master Journal List 2017 and JCR report 2016); (2) Comprehensive databases (Business Source Premier by Ebsco and Scopus). (3) Google Scholar; (4) extensive cross-disciplinary bibliography on FDI (consisting of several references), published in the different journals.

For this literature review, author design the literature selection criteria based on following characteristics, for instance, paper omitted that not dealing with FDI, and also that are not empirical or conceptual such as (book, commentaries, summaries of conference summaries, abstracts and keywords, executive abstracts, editorials, literature reviews and newspaper/magazine articles). In total, after duplication author identified almost 600 articles. To set up each paper's relevance, Author examined its abstract, title, and, methodology where necessary.

\section{Conclusion}

After the critical review of the literature, it is concluded that, as compare to total value of FDI, both the negative and the positive effects are revealed. It is very much interesting to see both the findings are separately fill the gap in the literature. So, the effect of FDI on the manufacturing growth is still under discussion and various studies have been conducted to check the impact of foreign investment on the overall economy. Some studies have observed a significant and positive, but some have examined negative and significant 
impact on the growth of the economy with the specific economic, financial, and technological situations of the host countries. This study will contribute to supplement the FDI and manufacturing growth literature and also explores the impact that FDI have on the manufacturing sector of Pakistan in terms of factor productivity. The study in hand attempted to relate literature insights with contributions that are relevant to the topic. Additionally, the analysis the variables are not developed in this study. Therefore, the main purpose to attempt that study is to provide a clear and comprehensive view of past investigated studies on FDI' including contextual approaches and practices.

\section{Future Recommendations}

This Review of the literature calls for further research on three different grounds. First, most of the studies conductance to investigate the FDI are used the RDL model, OLS regression and GMM approach. It is observed that during the literature review, a dynamic vector error correction model (VCEM) is implemented only limited studies to carry out the investigation. This VCEM procedure helps to ensures the time series dynamics that are under consideration is accurately captured, during endogeneity issues and causality issues are carrying out simultaneously. Additionally, any indirect effects and feedback that might be exists also be captured with the VECM procedure. Second, most of the FDI studies are conducted in the past mostly related to host country GDP and the economic growth, only few studies have been examined in the context of manufacturing growth, so it is suggested that further investigation required to reveal the proper execution of the manufacturing growth while FDI inflows are significant in the host country. Third, the studies are conducted in the past, analyzed in the context of south east Asian countries, for instance, Malaysia and US economy with the capital and growth in manufacturing sector in Japan, France, Germany and UK as well, as compare to under developed states. But limited investigation has been done in south Asia such as Pakistan. 


\section{References}

Agosin, \& Mayer. (2000). Foreign direct investment in developing countries. Does it Crowd in Domestic Investment.

Ahmed. (2012). Are the FDI inflow spillover effects on Malaysia's economic growth input driven? Economic Modelling, 29(4), 1498-1504.

Akinlo. (2004). Foreign direct investment and growth in Nigeria: An empirical investigation. Journal of Policy Modeling, 26(5), 627-639.

Alfaro, Chanda, Kalemli-Ozcan, \& Sayek. (2004). FDI and economic growth: the role of local financial markets. Journal of international Economics, 64(1), 89-112.

Almfraji, \& Almsafir. (2014). Foreign direct investment and economic growth literature review from 1994 to 2012. Procedia-Social and Behavioral Sciences, 129, 206-213.

An, \& Jeon. (2006). Demographic change and economic growth: An inverted-U shape relationship. Economics Letters, 92(3), 447-454.

Ashraf, Herzer, \& Nunnenkamp. (2016). The effects of Greenfield FDI and cross- border M\&As on total factor productivity. The World Economy, 39(11), 1728-1755.

Ataullah, \& Le. (2006). Economic reforms and bank efficiency in developing countries: the case of the Indian banking industry. Applied Financial Economics, 16(9), 653-663.

Balasubramanyam, Salisu, \& Sapsford. (1996). Foreign direct investment and growth in EP and IS countries. The economic journal, 92-105.

Balasubramanyam, Salisu, \& Sapsford. (1999). Foreign direct investment as an engine of growth. Journal of International Trade \& Economic Development, 8(1), 27-40.

Barrell, \& Holland. (2000). Foreign direct investment and enterprise restructuring in Central Europe. Economics of Transition, 8(2), 477-504.

Bengoa, \& Sanchez-Robles. (2003). Foreign direct investment, economic freedom and growth: new evidence from Latin America. European journal of political economy, 19(3), 529-545.

Blomström, Kokko, \& Mucchielli. (2003). The economics of foreign direct investment incentives Foreign direct investment in the real and financial sector of industrial countries (pp. 37-60): Springer.

Blonigen, \& Slaughter. (2001). Foreign-affiliate activity and US skill upgrading. Review of Economics and Statistics, 83(2), 362-376.

Borensztein, De Gregorio, \& Lee. (1998). How does foreign direct investment affect economic growth? 1. Journal of international Economics, 45(1), 115-135.

Campos, \& Kinoshita. (2002). Foreign direct investment as technology transferred: Some panel evidence from the transition economies. The Manchester School, 70(3), 398419.

Carkovic, \& Levine. (2005). Does foreign direct investment accelerate economic growth? Does foreign direct investment promote development, 195.

Castejon, \& Woerz. (2006). Good or bad? The influence of FDI on Output growth: An industry-level analysis: The Vienna Institute for International Economic Studies, wiiw.

Chakraborty, \& Nunnenkamp. (2008). Economic reforms, FDI, and economic growth in India: a sector level analysis. World development, 36(7), 1192-1212.

Chandran. (2009). Trade openness and manufacturing growth in Malaysia. Journal of Policy Modeling, 31(5), 637-647.

Chang, \& Wong. (2005). FDI and labour in China: the actors and possibility of a new working class activism.

Chen, Geiger, \& Fu. (2015). Manufacturing FDI in Sub-Saharan Africa. 
Pakistan Journal of Humanities and Social Sciences, 6(4), 2018

Chuang. (2007). FDI and domestic investment in Taiwan: An endogenous switching model. The Developing Economies, 45(4), 465-490.

Cipollina, Giovannetti, Pietrovito, \& Pozzolo. (2012). FDI and growth: what cross- country industry data say. The World Economy, 35(11), 1599-1629.

Dar, Bhatti, \& Muhammad. (2017). FDI and Economic Growth in Pakistan: A Sector Wise Multivariate Cointegration Analysis. Pakistan Development Review, 56(4), 67-90.

De Gregorio. (1992). Economic growth in latin america. Journal of Development Economics, 39(1), 59-84.

De Mello. (1999). Foreign direct investment-led growth: evidence from time series and panel data. Oxford economic papers, 51(1), 133-151.

Dunning. (1993). Internationalizing Porter's diamond. MIR: Management International Review, 7-15.

Dunning. (1998). Location and the multinational enterprise: a neglected factor? Journal of international business studies, 29(1), 45-66.

Durham. (2004). Absorptive capacity and the effects of foreign direct investment and equity foreign portfolio investment on economic growth. European economic review, 48(2), 285-306.

Edison, Levine, Ricci, \& Sløk. (2002). International financial integration and economic growth. Journal of international money and finance, 21(6), 749-776.

Eichengreen, \& Tong. (2007). Is China's FDI coming at the expense of other countries? Journal of the Japanese and International Economies, 21(2), 153-172.

Falki. (2009). Impact of foreign direct investment on economic growth in Pakistan. International Review of Business Research Papers, 5(5), 110-120.

Fauzel, Seetanah, \& Sannasee. (2015). Productivity spillovers of FDI in the manufacturing sector of Mauritius. Evidence from a dynamic framework. The Journal of Developing Areas, 49(2), 295-316.

Frankel. (2012). The natural resource curse: a survey of diagnoses and some prescriptions.

Frankel, Parsley, \& Wei. (2012). Slow pass-through around the world: a new import for developing countries? Open Economies Review, 23(2), 213-251.

Ghazali. (2010). Analyzing the relationship between foreign direct investment domestic investment and economic growth for Pakistan. International Research Journal of Finance and Economics, 47(1), 123-131.

Hussain. (2017). FOREIGN DIRECT INVESTMENT (FDI) AND ITS IMPACT ON THE PRODUCTIVITY OF DOMESTIC FIRMS IN PAKISTAN. Pakistan Business Review, 18(4), 792-812.

Jesson, Matheson, \& Lacey. (2011). Doing your literature review: Traditional and systematic techniques: Sage.

Johnson. (2006). The effects of FDI inflows on host country economic growth. The Royal Institute of technology. Centre of Excellence for studies in Science and Innovation http://www. infra. kth. se/cesis/research/publications/working papers.

Kaldor. (1966). Marginal productivity and the macro-economic theories of distribution: comment on Samuelson and Modigliani. The Review of Economic Studies, 33(4), 309-319.

Khan. (2007). Foreign direct investment and economic growth: the role of domestic financial sector: Pakistan Institute of Development Economics.

Libanio, \& Moro. (2006). Manufacturing industry and economic growth in Latin America: A Kaldorian approach. Paper presented at the Second Annual Conference for Development and Change. 
Liu, Daly, \& Varua. (2012). Determinants of regional distribution of FDI inflows across China's four regions. International Business Research, 5(12), 119.

Liu, \& Zou. (2008). The impact of greenfield FDI and mergers and acquisitions on innovation in Chinese high-tech industries. Journal of World Business, 43(3), 352-364.

Mahmood, \& Siddiqui. (2000). State of technology and productivity in Pakistan's manufacturing industries: Some strategic directions to build technological competence. The Pakistan Development Review, 1-21.

Mazenda. (2014). The effect of foreign direct investment on economic growth: Evidence from South Africa. Mediterranean Journal of Social Sciences, 5(10), 95.

Mencinger. (2003). Does foreign direct investment always enhance economic growth? Kyklos, 56(4), 491-508.

Nabli, \& Arezki. (2012). Natural resources, volatility, and inclusive growth: Perspectives from the Middle East and North Africa: International Monetary Fund.

Nadiri. (1993). Innovations and technological spillovers: National Bureau of Economic Research.

Nambiar, \& Balasubramaniam. (2016). Does ASEAN-India Trade Stimulate Income? A Cointegration Analysis Using the ARDL Approach. South Asia Economic Journal, 17(2), 295-314.

OECD. (2013). Education at Glance (pp. 440).

Pradhan, \& Singh. (2008). Outward FDI and knowledge flows: A study of the Indian automotive sector.

Rehman. (2016). FDI and economic growth: empirical evidence from Pakistan. Journal of Economic and Administrative Sciences, 32(1), 63-76.

Riahi-Belkaoui. (2003). Intellectual capital and firm performance of US multinational firms: a study of the resource-based and stakeholder views. Journal of Intellectual capital, 4(2), 215-226.

Rodrik, \& Subramanian. (2009). Why did financial globalization disappoint? IMF staff papers, 56(1), 112-138.

Schauer, Bhatt, Kirwan, Wolski, Aminian, Brethauer, . . Nissen. (2017). Bariatric surgery versus intensive medical therapy for diabetes-5-year outcomes. New England Journal of Medicine, 376(7), 641-651.

Sharafat, Rashid, \& Khan. (2014). The role of small and medium enterprises and poverty in Pakistan: An empirical analysis. Theoretical and Applied Economics, 18(4 (593)), 6780.

Singh. (2017). Does FDI Promote Productivity? A Deep Dive. Indian Journal of Industrial Relations, 52(3).

Szirmai, \& Verspagen. (2015). Manufacturing and economic growth in developing countries, 1950-2005. Structural Change and Economic Dynamics, 34, 46-59.

Trevino, Thomas, \& Cullen. (2008). The three pillars of institutional theory and FDI in Latin America: An institutionalization process. International Business Review, 17(1), 118133.

Wang. (2009). Manufacturing FDI and economic growth: evidence from Asian economies. Applied Economics, 41(8), 991-1002.

Wong, Loh, Lim, Lam, \& Lim. (2015). Impact of macroeconomic variables on manufacturing sector growth in Malaysia. UTAR.

Xu. (2000). Multinational enterprises, technology diffusion, and host country productivity growth. Journal of Development Economics, 62(2), 477-493.

Yasmin, Hussain, \& Chaudhary. (2003). Analysis of factors affecting foreign direct investment in developing countries. Pakistan Economic and Social Review, 59-75. 
Younus, Sohail, \& Azeem. (2014). Impact of foreign direct investment on economic growth in Pakistan. World Journal of Financial Economics, 1(1), 2-5.

Zaman, Shah, Mushtaq Khan, \& Ahmad. (2012). Macroeconomic factors determining FDI impact on Pakistan's growth. South Asian Journal of Global Business Research, 1(1), 79-95.

Zeb, Qiang, \& Rauf. (2013). Role of foreign direct investment in economic growth of Pakistan. International Journal of Economics and Finance, 6(1), 32.

Zikmund, Babin, Carr, \& Griffin. (2013). Business research methods: Cengage Learning. 